\title{
Fungal endocarditis of native valves
}

\author{
Sara Pipa, ${ }^{1}$ Cátia Dias, ${ }^{1}$ José Ribeiro, ${ }^{2}$ Tiago Gregório ${ }^{1}$
}

'Department of Internal Medicine, Centro Hospitalar de Vila Nova de Gaia Espinho EPE, Vila Nova de Gaia, Portugal ${ }^{2}$ Department of Cardiology, Centro Hospitalar de Vila Nova de Gaia Espinho EPE, Vila Nova de Gaia, Portugal

\section{Correspondence to Dr Sara Pipa, six.pipa@gmail.com}

Accepted 31 October 2018

\section{DESCRIPTION}

A 49-year-old man with history of hepatitis C and former intravenous drug addict under methadone therapy was hospitalised in an intensive care unit after sustaining severe burn injuries to the face, airway and left hand. During hospitalisation, he developed ventilator-associated pneumonia with Klebsiella pneumoniae bacteraemia. Antibiotic therapy was delivered with amoxicillin/clavulanic acid and the infection resolved, but on the 26th day of hospitalisation fever returned, along with new onset increase in inflammatory markers. Four blood cultures were harvested from two distinct venous punctures and a fifth was collected from a central venous line, which was later replaced. All the blood cultures were positive for Candida tropicalis and the patient was treated with a 3-week course of micafungin for candidaemia. The patient was discharged home on the 63rd day of hospitalisation after two sets of four negative control blood cultures.

One month later, he returned to the Emergency Department complaining of a 2-week history of asthenia, pleuritic chest pain and fever. At physical examination, he was emaciated and with poor general condition. His blood pressure was $100 / 55 \mathrm{~mm} \mathrm{Hg}$, heart rate was 75 beats per minute and temperature was $102.2^{\circ} \mathrm{F}$. His lung and heart sounds were normal and there was no peripheral oedema or cutaneous lesions. His ECG was normal and blood tests showed an increased white cell count $(12500 \mathrm{U} / \mathrm{L})$ along with an elevated $\mathrm{C}$ reactive protein $(1661 \mathrm{mg} /$ $\mathrm{dL}$ ). The chest X-ray was also normal, but the transthoracic echocardiogram showed evidence of a large mass in the aortic valve, with moderate

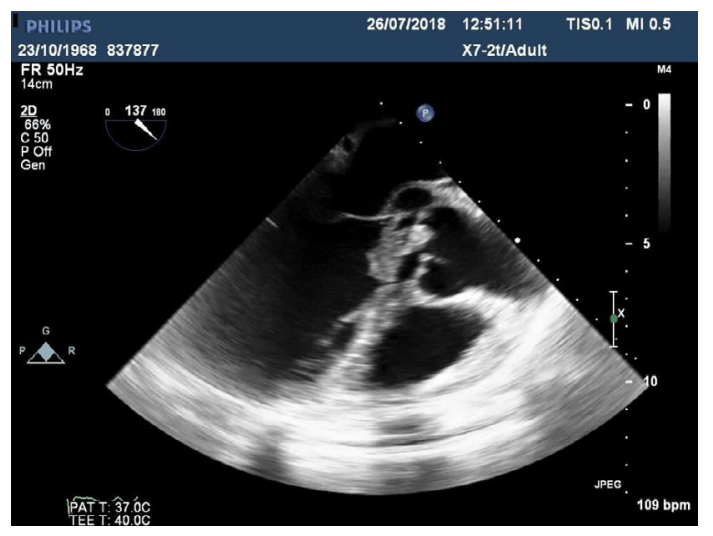

Video 1 Transoesophageal echocardiogram. Thickened aortic valve, with destruction of the cusps and a large adherent vegetation protruding towards the left ventricular outflow tract; severe aortic insufficiency.

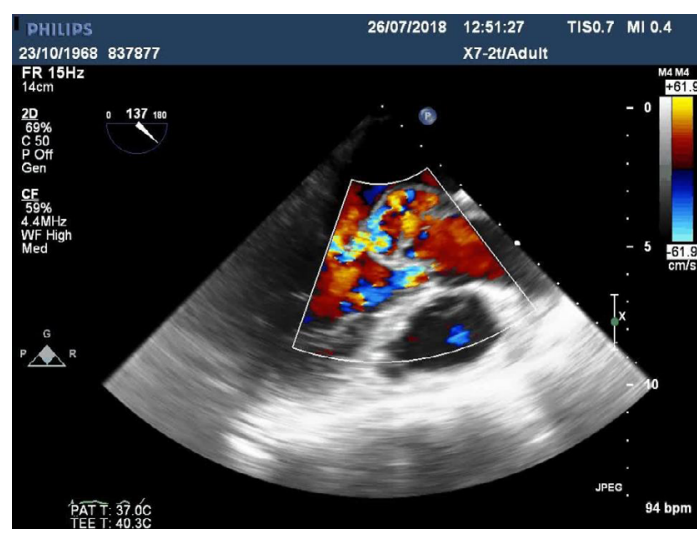

Video 2 Transoesophageal echocardiogram. In the aortic root posterior region, a hypoechoic space is seen with flow in the interior communicating with the left ventricular outflow tract, compatible with a pseudoaneurysm of the aortic root extending to the mitral-aortic fibrosa. Poor coaptation of the mitral valve leaflets resulting in moderate to severe insufficiency.

regurgitation and an abscess adjacent to the valsalva sinus. Blood cultures were collected, and the patient was empirically started on vancomycin and gentamicin. On the first day of hospitalisation, C. tropicalis was isolated in blood cultures and a transoesophageal echocardiogram was performed (videos 1 and 2). The diagnosis of fungal endocarditis was made. The patient was started on liposomal amphotericin $B$ and underwent cardiac surgery, during which direct involvement of both the aortic and mitral valves by the infectious process was noticed. Both valves were replaced by mechanical prosthesis and amphotericin was continued for 8 weeks after surgery. Control blood cultures were

Learning points

- Fungal endocarditis is a rare disease (less than $2 \%$ of all cases of infectious endocarditis), with a mortality rate of about $50 \%$.

- Risk factors have changed dramatically in the last decades and include prosthetic valves, longterm vascular lines, broad-spectrum antibiotic exposure, immunocompromised patients, complex non-cardiac surgery and intravenous drug users (much less affected these days). Our patient had a previous fungaemia in the presence of a central venous catheter, which is in agreement with the described risk factors.

- Treatment should be combined: antifungal therapy for a minimum of 6 weeks and surgical replacement of the infected valve, if possible. 
negative and a repeat echocardiography showed absence of vegetations. Mycological examination of the valves was also positive for C. tropicalis.

Contributors All authors contributed substantially to the conception of this manuscript. SP and CD were responsible for reporting the case. SP and JR were responsible for videos preparation. SP and TG wrote the learning points and performed the bibliographic research. SP had full responsibility for the final work.

Funding The authors have not declared a specific grant for this research from any funding agency in the public, commercial or not-for-profit sectors.

Competing interests None declared.
Patient consent Obtained.

Provenance and peer review Not commissioned; externally peer reviewed.

\section{REFERENCES}

1 Badiee P, Amirghofran AA, Ghazi Nour M, et al. Incidence and outcome of documented fungal endocarditis. Int Cardiovasc Res J 2014;8:152-5.

2 Gould FK, Denning DW, Elliott TS, et al. Guidelines for the diagnosis and antibiotic treatment of endocarditis in adults: a report of the Working Party of the British Society for Antimicrobial Chemotherapy. J Antimicrob Chemother 2012;67:269-89.

3 Tattevin P, Revest M, Lefort A, et al. Fungal endocarditis: current challenges. Int J Antimicrob Agents 2014;44:290-4.

Copyright 2018 BMJ Publishing Group. All rights reserved. For permission to reuse any of this content visit https://www.bmj.com/company/products-services/rights-and-licensing/permissions/

BMJ Case Report Fellows may re-use this article for personal use and teaching without any further permission.

Become a Fellow of BMJ Case Reports today and you can:

- Submit as many cases as you like

- Enjoy fast sympathetic peer review and rapid publication of accepted articles

- Access all the published articles

Re-use any of the published material for personal use and teaching without further permission

For information on Institutional Fellowships contact consortiasales@bmjgroup.com

Visit casereports.bmj.com for more articles like this and to become a Fellow 